\title{
Research Article: Impact of front line demonstration on production of summer moong in Barnala district
}

\author{
Article Chronicle : \\ Received : \\ 24.10.2017; \\ Revised : \\ 23.12.2017; \\ Accepted : \\ 09.01.2018
}

\section{KEY WoRDS:}

Moong, Front line demonstration, Cost of cultivation, Netreturn, Yield
Author for correspondence :

\section{K.S. Matharu} Krishi Vigyan Kendra, Handiaya, Barnala (Punjab)India

Email:matharu38@ rediffmail.com

See end of the article for authors' affiliations

\section{K.S. Matharu and P.S. Tanwar}

SUMMARY : Pulse crops have been the backbone of agricultural economy of India from time immemorial. The productivity of moong crop in Barnala district of Punjab state is low due to non-adoption of improved package of practices. Therefore, efforts have been made through front line demonstrations (FLD) to demonstrate improved production technologies to increase productivity of moong crops in the district. Twenty front line demonstrations were conducted on summer moong covering an area of 8.0 hectare and latest production and protection technologies were exhibited. Farmers were randomly selected from adopted villages for conducting front line demonstration. A $13.70 \%$ increase in yield of moong under the demonstration plots over farmer's practices was recorded. Improved variety of moong SML 668 gave the highest yield $11.08 \mathrm{q} / \mathrm{ha}$ and $11.15 \mathrm{q} / \mathrm{ha}$ as compare to the farmers' practiced variety which gave $9.80 \mathrm{q} / \mathrm{ha}$ and $9.75 \mathrm{q} / \mathrm{ha}$ yield in the year 2016 and 2017, respectively. The mean extension gap, technology gap and technology index were found $1.34 \mathrm{q} / \mathrm{ha}, 0.14 \mathrm{q} / \mathrm{ha}$ and $1.20 \%$, respectively. Recommended technologies gave higher mean net return of Rs. 35365 per hectare with a benefit cost ratio 3.25 as compared to farmers practice with mean net return of Rs. 29205 per hectare with a benefit cost ratio 2.86 .

How to cite this article : Matharu, K.S. and Tanwar, P.S. (2018). Impact of front line demonstration on production of summer moong in Barnala district. Agric. Update, 13(1): 62-66; DOI : 10.15740/HAS/AU/13.1/6266. 